\title{
Translation Teaching Research for English Major based on Multimedia and Network Environment
}

\author{
W.Y. Zhang* \& X. Liu \\ Foreign Language Institute, Harbin University of Science and Technology, Harbin, P. R. China \\ J.L. Cui \\ State Key Laboratory for Manufacturing Systems Engineering, Xi'an Jiaotong University, Xi'an, P. R. China \\ School of Mechanical Engineering, Xi'an Jiaotong University, Xi'an, P. R. China
}

*Corresponding author

\begin{abstract}
English translation is a powerful tool for international communication and learning a powerful tool in the world civilization and scientific and technological knowledge. In order to ensure the quality of teaching, develop students' information literacy, cultivate students' innovative spirit and practical ability of translation, further deepen the English education reform and comprehensively promote quality education, under the current background of actively promoting the modernization and information of education, according to the current existing problems of translation teaching for English major, we mainly analyzed the status of translation teaching, discussed the feasibility of translation teaching for English major based multimedia network environment, and studied the construction of translation teaching aiming at improving the translation teaching effectiveness and students' English language proficiency.
\end{abstract}

KEYWORD: Translation teaching; English major; Multimedia; Network

\section{INTRODUCTION}

With the rapid development and progress of society, English has become a powerful tool for the international communication and learning the world civilization and scientific and technological knowledge. Traditional college English teaching emphasizes only on reading and writing ability of English with ignoring other language abilities, which results in widespread emergence of the current 'dumb English' phenomenon. Therefore, to change the current phenomenon, it is necessary to strengthen the cultivation of comprehensive language skills including translation. However, as a foundation course of English major, translation course still has many deficiencies in its teaching mode, and translation talents can not properly meet demands of the society. To change this situation, it is an urgent task for us to take more innovative and extensive teaching methods and means in the translation teaching for English major, to make the translation teaching face new challenges and opportunities.

Currently, multimedia and network communication technology has become the main representative of modern information technology, and has been applied to college English teaching. Therefore, under the current background of actively promoting the modernization and information of education, it is necessary to deeply study the translation teaching for English major based on multimedia network environment, to carry out the reform of teaching methods, to adjust teaching strategies, and to build a new teaching mode, for the integration between network environment and translation teaching, cultivation of students' innovative ability and practical ability in English translation, and promotion of quality education $[1,2]$.

\section{THE STATUS OF TRANSLATION TEACHING FOR ENGLISH MAJOR}

English translation, as an independent discipline, plays an important role in the university courses. But there is not a clear definition of training objectives and requirements for translators. So there is a huge room for improvement in translation course mode. Currently, the translation teaching mainly faces the following problems.

\subsection{Unsystematic and unscientific translation teaching materials}

Translation textbooks play a fundamental role in the translation teaching. Teachers teach primarily through textbooks, and students also learn by textbooks. Therefore, the quality of translation teaching is completely affected by the quality of translation materials. Also, in most colleges and universities, the teaching materials lack 
systematicness and scientificness with pure stacks of theoretical knowledge and illustrations, which focus seriously on the translation of words and sentences with the lack of the key teaching for contexts and so on.

\subsection{Unreasonable translation teaching methods and means}

Currently, college English translation teaching means is relatively simple, and the idea is relatively old. Usually, a teacher teaches translation theory and skills step by step, and then students slavishly imitate and drill every gesture and motion in the classroom one by one. And the teacher evaluates students' practice to achieve "stimulus - response strengthening" effect and the learning and application of English translation through repeated mechanical training. In this teaching mode, the teachers did not implement such as humanistic theory in translation teaching often valued more classroom teaching than the extra-curricular practices. Teachers teaching translation skills and subsequent students practicing the translation are the main teaching mode. Due to the simple mode, the teachers will have greater teaching pressure, affecting the quality of teaching. In addition, in the English translation teaching methods, lacking real context of three feet of the podium-blackboardchalk, it will lead to disjointed teaching between theory and practice. It is likely to cause the consequences that the learning can not be used, which will gradually weaken the students' enthusiasm of translation learning, reducing translation teaching effectiveness. In addition, due to the lag reasons of publishing and printing and inconformity between textbooks and current era, students devote themselves to imitate and exercise the methods and skills of translation from the book with inability to cope with the complex material beyond the tutorial scope in the future.

\subsection{Ignorable individual differences of students in translation teaching}

Translation is a teaching with practical significance. So teachers should focus on the personality of different students in the teaching process and stimulate students' learning interest through a variety of interactive teaching process. However, in the current translation teaching, teachers focus on repetitive explanations and exercises, and lack proper teaching strategies, which lead to the missing practical exercises opportunities and low learning interest in or outside the classroom teaching. Consequently, the teachers can not guarantee the quality of teaching.

\section{FEASIBILITY OF TRANSLATION TEACHING FOR ENGLISH MAJOR BASED ON MULTIMEDIA AND NETWORK}

Since the successful application of computer technology in education field, the reform of college English teaching from the 'computer-assisted language instruction' (CALI) stage to the 'Integrating IT into the curriculum' (IITC) stage in modern educational technology advocacy, the new teaching ideas and patterns are in constant exploration. All colleges and universities should make full use of multimedia and network technology, take the new teaching mode based on modern information technology, especially network technology support, to improve the original classroom-based instruction teaching mode without the restrictions of time and place. In addition, students can learn English by personalized and independent self-study way in their spare time.

In order to adapt to the demands of college English translation teaching and the needs of students' learning English in modern society, modern technology becomes the basis, especially multimedia network technology, to improve the effectiveness of translation teaching and cultivate students' ability and interests of self-learning English. In English major, translation teaching based on multimedia and network environment is one of the main contents of college English teaching reform, and one of the important issues to be explored in depth.[3,4] However, the awareness of training teachers and students to use multimedia network technology for assisting English translation teaching, and the improvement of multimedia network technology level, are imperative to promote multimedia network teaching.

English translation teaching under multimedia network environment, with features like a large amount of information, strong interaction, prominent multimedia function, strong humanized characteristics, can effectively overcome the shortcomings of the traditional mode, and greatly improve the efficiency and effectiveness of English translation teaching. Generally speaking, multimedia network translation teaching has following advantages. First, multimedia network can store large amounts of teaching resources and establish classified multimedia translation teaching material library. We can quickly and easily retrieve information and timely update the teaching material to ensure the timeliness of translation teaching. Second, multimedia network technology can allow teachers to give full consideration of students' nonintelligence factors in learning in order to achieve individualized teaching. Teachers just need to sit in front of the computer, present the corresponding translation teaching materials on each student's computer to create an immersive realism according 
to the students' interests and professional characteristics. Students can learn translation skills and better perceive the objective world in computer simulations of real-world. Third, through the monitoring function of multimedia network, teachers will be able to grasp the situation of students learning and practicing English translation, and timely give correct guidance. Fourth, multimedia network technology can provide intelligent evaluation and testing methods, so students can always check their mastery of translation knowledge, and teachers can clearly understand students' learning.

\section{ESTABLISHMENT OF TRANSLATION TEACHING MODE FOR ENGLISH MAJOR BASED ON MULTIMEDIA AND NETWORK ENVIRONMENT}

Change of English teaching mode is not just in teaching activities or teaching methods, but in teaching philosophy shifting from the teaching mode of a teacher-centered with simply teaching language skills and knowledge to the teaching mode of a student-centered with more attention on training language proficiency and self-learning ability. As the application of multimedia network technology for English translation teaching, it can emphasize individualized teaching and learning, and give full play to the computer repeated training role. In addition, teachers can impart the translation skills and knowledge and tutor students to cultivate translation skills. So under the teachers' guidance, according to their own characteristics, level and time, students can choose the appropriate translation learning materials and rapidly improve English translation ability with the help of computer to achieve the best learning results. However, the establishment of translation teaching environment, based on multimedia and network environment, is not a simple problem, but a system which needs many various levels of support and protection. It can be strengthened from the following several important aspects. [5,6]

\subsection{Hardware support of schools and English translation environment creation of communities}

Schools should provide adequate multimedia network teaching facilities for teachers and students, such as network-based multimedia classrooms, computer rooms, electronic reading rooms, language lab and comprehensive broadband network coverage in the dormitory area, so that students can take advantage of their spare time for independent selflearning. In addition, in order to cultivate students' interest and communicate each other, schools should play the role of each community. Then, each community can actively organize forms of English translation learning environment, such as English salon, English horn, the Anglo-American film appreciation Association, And using the language lab, multimedia classrooms or electronic reading room and other facilities and resources, the training and cultivation of the English translation can be strengthened to improve English translation level.

\subsection{Changing ideas and roles and studying to improve the operation ability of multimedia network technology as teachers}

Meanwhile, focusing on classroom teaching, teachers should be the mentors and supervisors of language learning and create a safe, comfortable learning environment for students. And teachers should arrange extracurricular English translation task, then encourage students to take advantage of this favorable environment for voluntarily studying English. Also, in addition to books, tapes, dictionaries, encyclopedias and other teaching materials, the adequate learning resources should be provided. Teachers should guide students to cover English songs, enjoy the English original movies, listen to English news, such as VOA and BBC radio broadcasts, or CNN video news. At the same time of learning English translation, students can imitate the language and forms of dialogue, and observe body language and facial expressions of different kinds in different situations and context. On the basis of discussions exchange between teachers and students, for some difficulty or the different viewpoints highlighting, teachers should explain, inspirit and answer the corresponding questions, and guide students to get the right conclusions. Due to multimedia network teaching being a teaching mode based on students' active participation and selfcontrol, the open teaching environment with multiple ways and multiple modes should be creatively provided for students.

In multimedia network English translation teaching, the main work of teachers is to design teaching based on language teaching law. Through creating situation in accordance with the requirements of the teaching content, the student is introduced directly into the language activities. Therefore, teachers, engaging in multimedia network teaching, should have improvement in the knowledge structure, teaching standards and teaching methods during the process of integrating multimedia network technology in their teaching. In the knowledge structure, the use of multimedia capabilities, the writing of courseware and network technical knowledge will be constraints for teachers' qualifications in multimedia network teaching. In the teaching level, teachers, using multimedia network teaching, should timely deal with students' information, supervise and guide the implemented learning methods, have flexible working capabilities 
and dedication. In teaching methods, there are fewer opportunities between teachers and students, teachers need to sufficiently learn to understand the psychology and attitudes of students in the multimedia network teaching process, and help them to analyze and solve the encountered study difficulties and troubles. Therefore, teachers should reinforce learning, and actively apply multimedia network technology to routine English translation teaching, especially the Internet network environment, multimedia courseware, and gradually improve the ability and application of multimedia network technology in practice.

\subsection{Changing ideas and having the appropriate learning ability and habits as students}

In English translation teaching, students should become the center of classroom activities. Under the network environment, through feedback, two-way learning mode and actively converting thinking ways, students should adapt to college relaxed learning environment soon. And they should be also familiar with the learning conditions and status of multimedia network, and actively participate translation teaching activities in classroom. While conducting independent study, social practice participation should be chosen to exercise their English translation capability. At the same time, students also pay attention to the progress and development of science and technology, and properly use a variety of advanced equipment.

\subsection{Full-service and multi-dimensional translation teaching based on the multimedia and network environment}

Classroom teaching is essential, but teaching English, in the limited time and particular class space, is not conducive to take advantage of multimedia network. So in a limited time and space, teachers should strive to teach through a variety of English professional knowledge and skills in English translation with regulations and outline, and then arrange homework for students. The students can use multimedia network system to digest, absorb, study or prepare the translation work. In extracurricular learning, students can also get teachers' instruction through multimedia network system. And teachers can implement teaching, supervision and inspection to facilitate students learning English through the guidance of teachers, and communicating like with teachers face to face. In order to make each student have opportunity and be willing to speak, teachers should integrate online learning and speaking activities into companion study, in the form of group discussions, reporting, and other learning activities for guiding students to identify and solve problems through self-assessments as far as possible.

\section{CONCLUSION}

Translation teaching for English major, based on multimedia and network environment, has become an indispensable effective tool for communicating and learning in today's society. Based on the use of multimedia network and its rich resources, English translation teaching is becoming an integral part of college English. Therefore, the multimedia network translation teaching is a systematic project, involving the concept of teaching ideas, many aspects of teaching content, teaching process, teaching mode, teaching conditions, and a modern teaching faulty construction. Using multimedia technology and network resources in translation teaching can change the teacher-student teaching philosophy, and build a modern learning environment and habits. Beginning with emphasis on English translation teaching, it should be improved from teaching philosophy to teaching methods and standards, to improve English language learning ability and level with increasing the international competitiveness of high quality talent.

\section{ACKNOWLEDGMENTS}

This project was supported by the Philosophy and Social Science Planning Program of Heilongjiang Province, China (12B066), Research Support Program of Xi'an Jiaotong University, China (08142037). All the authors gratefully acknowledge their support.

\section{REFERENCES}

[1] Chen, J. 2005. On Learner-centeredness in Computer-and Classroom-based Multimedia College English Teaching Model. Media in Foreign Language Instruction 5: 000.

[2] XIE, J.X., \& DONG, J.Q. 2010. On Teaching College English Listening-Based on Multi-Media and Multi-Modal Teaching and Learning. Computer-Assisted Foreign Language Education 6:004.

[3] Chai, C.S., Ling Koh, J.H., Tsai, C.C., \& Lee Wee Tan, L. 2011. Modeling primary school pre-service teachers' Technological Pedagogical Content Knowledge (TPACK) for meaningful learning with information and communication technology (ICT). Computers \& Education 57(1):1184-1193.

[4] Han, S. 2014. Research on new English teaching mode based on informatization. Journal of Chemical and Pharmaceutical Research 6(6):635-642.

[5] Li, R. 2014. Key Technology on Construction of College English Multimedia Teaching Website. Applied Mechanics and Materials 433: 2480-2483.

[6] Jia, G. 2003. Modern networks and reform of college English teaching mode-Design and implementation of webbased college English teaching mode. Foreign Language World 6: 004. 